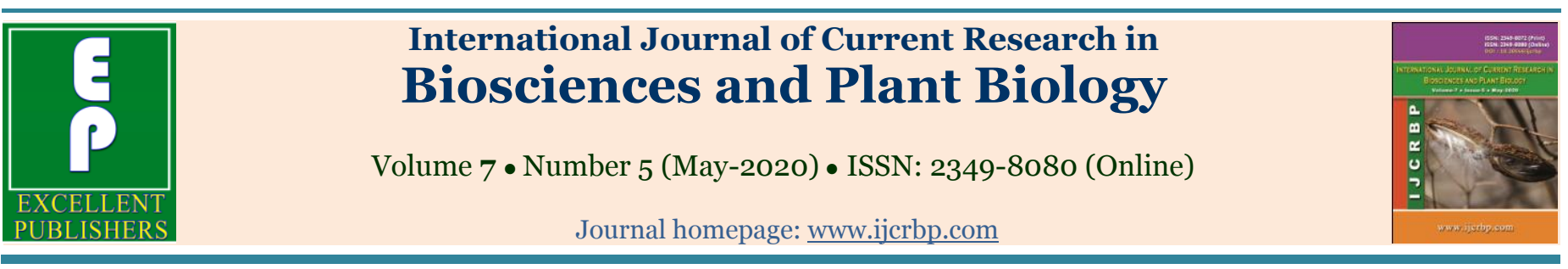

\title{
Yield and yield attributes of exotic and local Okra (Abelmoschus esculentus) cultivars in acid soil
}

\author{
Md. Rayhan Ahmed Shawon, A. F. M. Saiful Islam and Sharifunnessa Moonmoon*
}

Department of Crop Botany and Tea Production Technology, Faculty of Agriculture, Sylhet Agricultural University, Sylhet-3100, Bangladesh

${ }^{*}$ Corresponding author; e-mail: moondj311@yahoo.com

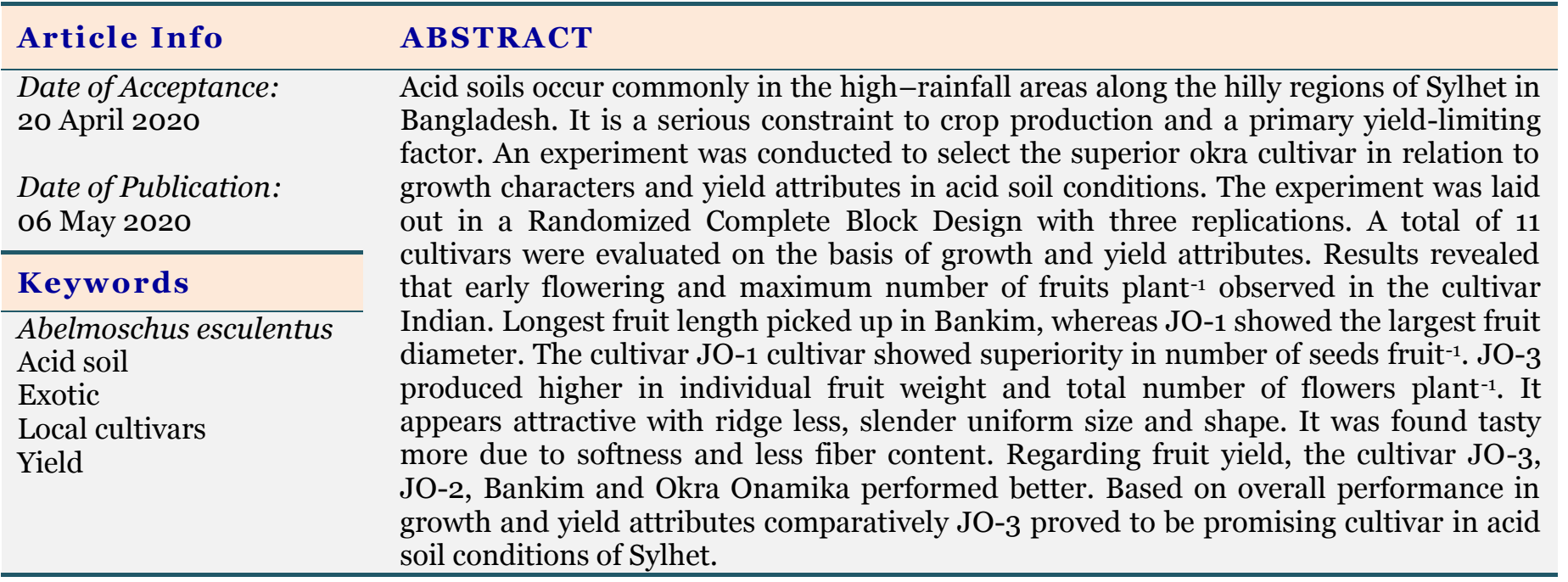

\section{Introduction}

Okra plant (Abelmoschus esculentus L.) belongs to the family Malvaceae is being cultivated in many sub-tropical and warmer parts of the temperate regions (Gopalakrishnan, 2007; Varmudy, 2011) including Bangladesh as having health and economic benefits along with yield potentiality. This plant is known by many local names in different parts of the world (lady's finger in England, Gumbo in U.S.A., Bhindi in India). Farmers of our country mainly cultivate okra as vegetable, also used as salads, soups and stews, fresh or dried, fried or boiled (Ndunguru and Rajabu, 2004). The pods compose healthy amounts of vitamin A, and flavonoid anti-oxidants such as beta-carotene, xanthin and lutein. In Bangladesh, vegetable production is not uniform round the year and per capita consumption of vegetable is much lower than the standard requirement. Okra is cultivated throughout Bangladesh but its average yield is low. According to the Bangladesh Bureau of Statistics the total production of Okra was about 43000 metric tons produced from 26000 acres of land and the average yield of Okra was $4.1 \mathrm{t} \mathrm{ha}^{-1}$ in the year 
2010-2011 (BBS, 2013). The average yield of Okra is much lower in the country as compared to the developed countries where the yield is as high as 10-15 t ha $^{-1}$. Okra rarely reaches its maximum yield potential due to several constraints such as soil character, weed management, fertilize soil, tillage practice, low yielding varieties and sub-optimal planting density. However, integration of different sources of nutrients has proved more superior to individual components with respect to yield, quality and nutrient uptake (Abusaleha and Shanmugavelu, 1988).

Sylhet is one of the special AEZ of Bangladesh due to its typical soil characters as well as acidity. $\mathrm{pH}$ of the soil of the regions ranges from 4.5-6.5. Production of most of the crops are limited here, as soil acidity is common in the region where precipitation is high enough to leach appreciable amounts of exchangeable bases from the surface of soil. Adverse climatic conditions such as heavy rainfall, high humidity, seasonal flooding, fog etc. are the other barriers for the vegetable production in the region. Acid soils possess high concentration of $\mathrm{Al}^{3+}, \mathrm{Fe}^{3+}, \mathrm{Mn}^{2+}$, deficient in $\mathrm{P}, \mathrm{B}$ and $\mathrm{Mo}$ and low availability of bases which together causes reduction in crop yield. Acid soils, especially the Ultisols and Oxisols usually have problems associated with aluminum toxicity, low nutrient status, nutrients imbalance and multiple nutrient deficiencies (Sanchez et.al., 1987). Total cultivable land in Bangladesh is 1235336 ha. In Sylhet Division Okra is only cultivated in 880 ha of land of which 272 ha belongs to Sylhet District. The total production of Okra in Sylhet District is only about 1904 metric tons (Anonymous, 2012). Low production area and lack of suitable variety has resulted in poor production of okra in the region. The production is too low to meet up the demand and some well-suited varieties could improve the situation.

In view of the above circumstances, expansion of Okra cultivation in acidic soil is necessary. Selection of suitable cultivars is essential to improve the production of Okra to fill the crisis of vegetable in summer, in the region as well as in the country. Considering the aforesaid scopes and constraints the present investigation was undertaken to find out the cultivars having early fruit bearing and higher yielding abilities with longer harvesting duration in acid soil.

\section{Materials and methods}

Eleven cultivars of Okra (treatments) viz., BARI Dherosh-1 (control), JO-1, JO- 2, JO-3, JO-4, Orka Onamika, Bankim, Durga, Indian, China and Thai of which four advanced lines collected from Japan, four cultivars collected from India, one collected from Thailand, one from China and a local variety BARI Dherosh-1 were used as experimental materials. The individual plot was laid out in a Randomized Complete Block Design with three replications. The experimental field was divided in 3 blocks representing 3 replications and each block had 11 individual plots. Treatments were randomly allotted in each block.

Okra seeds were sown in lines with a spacing of $0.50 \mathrm{~m}$ and $0.40 \mathrm{~m}$ for row to row and plant to plant, respectively. Six Okra plants from each plot were selected randomly for collecting data. The plants of the outer rows and the extreme end of the iddle rows were excluded from data collection. The data collection on different yield and yield contributing parameters such as number of flowers, fruits, aborted fruits, fruit length, diameter, number of seeds fruit $^{-1}$, seed weight, individual fruit weight, fruit yield $(\mathrm{kg}$ day $^{-1}$ ), fruit yield ( $t \mathrm{ha}^{-1}$ ), edible quality of fruits were recorded. The average numbers of fruits plant $^{-1}$ was deducted from the average number of flower per plant to get number of aborted fruit per plant. Girth of ten randomly selected fruits from each plot were measured by a slide calipers at three points (Tip, Middle and Base) of fruit and finally the mean was calculated. Seeds of ten randomly selected fruits from each plot at physiological maturity were counted and finally mean was calculated. Mean weight of randomly selected 100 seeds were measured using an electrical balance and was recorded in gram (g). Total yield of green fruits were recorded and then divided by the total harvest duration (days). The weight of edible green fruits at each harvest was noted plot wise and finally total weight was calculated ha-1.

Edible quality of fruits of all cultivars of Okra was provided to 10 people for consumption. The comments and opinions of the selected consumers were used for judging the edible quality of fruits of Okra cultivars. The data were analyzed statistically using MSTAT-C (Russel, 1986) software. 


\section{Results and discussion}

The number of days required to produce first flower differed significantly among the cultivars (Fig. 1). The cultivar BARI Dherosh-1 produced flower early (37 days after sowing) which were statistically similar to other cultivars (JO-4, Durga and Thai) and the cultivars Indian showed delayed flowering (41 days) among the cultivars. The rest of the varieties produced first flower in between them. Winter crops required more days to flower (Hossain, 1997) as low temperature affected the vegetative growth and transition from vegetative to reproductive phase delayed. Halim (2008) observed significant differences in days to first flowering (36 to 44 days) among seven cultivars of Okra genotypes which is similar with our current research. Saha (2013) reported that the first flowering ranged between 35 and 54 days among the cultivars of okra. Islam et al. (2000) also showed variation in days to first flowering. Saifullah et al. (2009) worked with 121 genotypes of Okra and found indicative variation in days to first flowering.

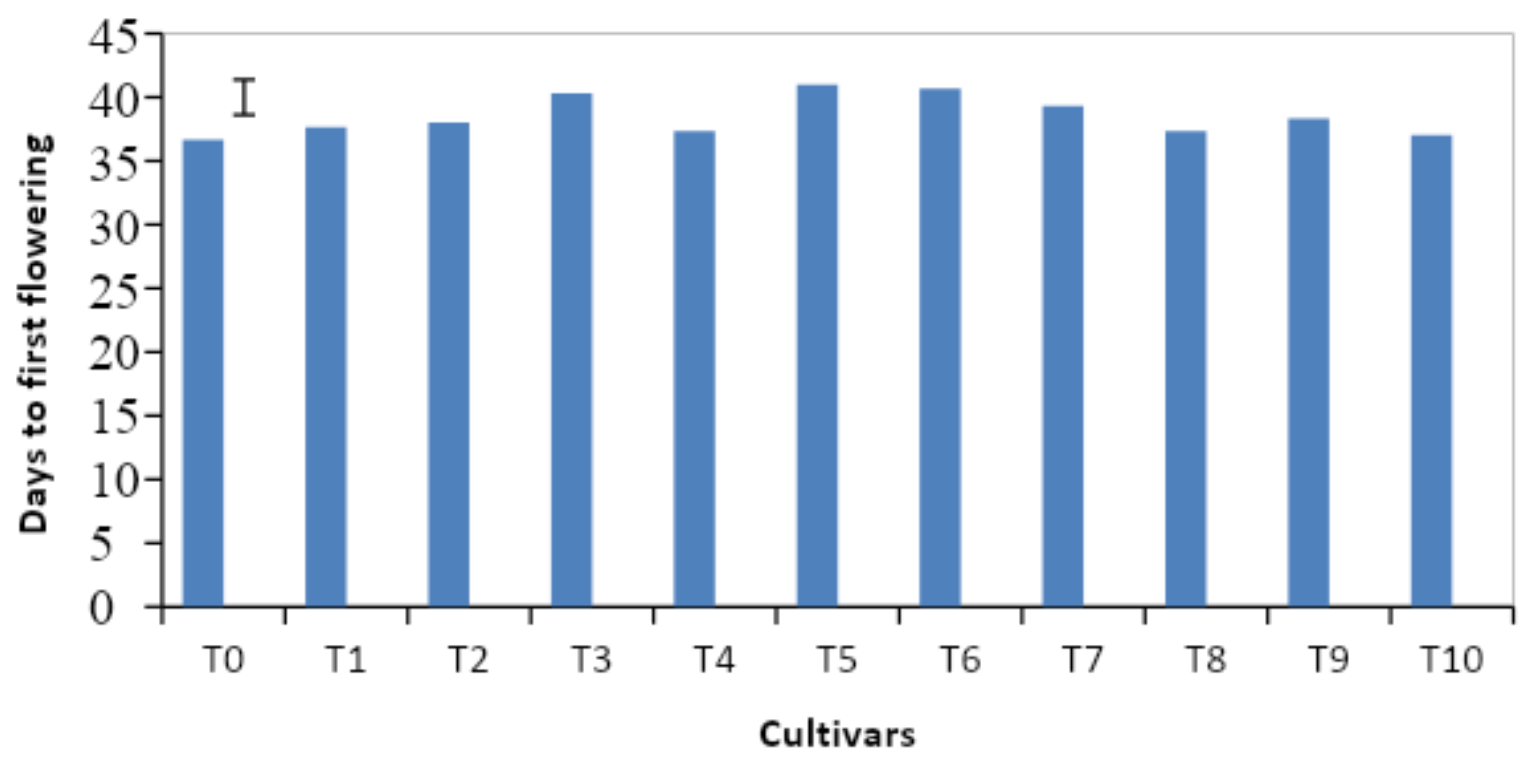

Fig. 1: Days to first flowering of different Okra cultivars. Vertical bar represents standard error. $T_{0}=$ BARI Dherosh-1 (Control), $\mathrm{T}_{1}=\mathrm{JO}-1, \mathrm{~T}_{2}=\mathrm{JO}-2, \mathrm{~T}_{3}=\mathrm{JO}-3, \mathrm{~T}_{4}=\mathrm{JO}-4, \mathrm{~T}_{5}=$ Indian, $\mathrm{T}_{6}=$ Orka Onamika, $\mathrm{T}_{7}=$ Bankim, $\mathrm{T}_{8}=$ Durga, $\mathrm{T}_{9}=$ China and $\mathrm{T}_{10}=$ Thai.

Significant variation was also observed (37-60) in total no. of flowers plant ${ }^{-1}$ (Table 1). Number of flowers varies 29 to 59 in Okra cultivar research of Saha (2013). There was significant variation among the cultivars regarding the number of fruits plant $^{-1}$ (Table 1). The greatest quantity of fruits (39) plant $^{-1}$ was obtained in Indian followed by China (39). On the other hand, least number of fruits (27) plant $^{-1}$ was in $\mathrm{JO}-4$ which was significantly lower than other cultivars. Number of fruits depends on flower production and fruit setting capability of the cultivars. Saha (2013) spectacled 14 to 41 on the basis of total number of fruits plant $^{-1}$. Like contrast in number of fruits plant $^{-1}$ was also reported by Islam et al. (2000) and Halim (2008). Results showed that the eleven cultivars differ significantly in respect of total no. of aborted fruits plant ${ }^{-1}$ (Table 1). The highest aborted fruits plant $^{-1}$ observed in JO-3 (30) followed by the cultivar Durga (22). The highest fruit setting was found in the variety China (75.80\%) which is statistically similar with Bankim and Orka Onamika.

Fruit length varied significantly among the cultivars studied (Fig. 2). Longest fruit length $(12.40 \mathrm{~cm})$ was noted in Durga followed by Thai and BARI Dherosh-1. The shortest fruit length (6.59) was recorded in China. Fruit length differs between 12.28 and $15.55 \mathrm{~cm}$ in the work of Saha (2013). Typical variation in fruit length among different genotypes of Okra was recorded by several researchers (Halim, 2008; Prakash et al. 2001). Saifullah et al. (2009) also displayed the variation in fruit length from 9.80 to $17.25 \mathrm{~cm}$ among 121 genotypes of Okra. 
Table 1. Variations in no. of internodes plant ${ }^{-1}$, internodal length, total number of flowers plant ${ }^{-1}$, aborted fruits plant ${ }^{-1}$ (no.), fruit plant ${ }^{-1}$, fruit setting (\%), picking duration of fruit in different Okra cultivars.

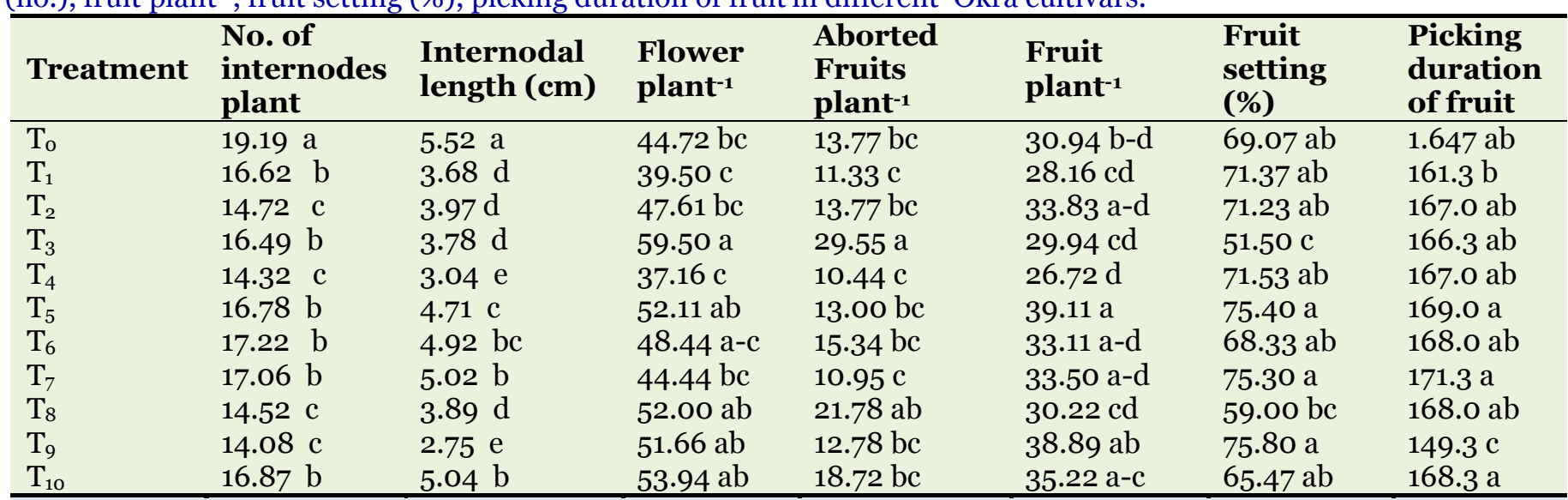

Within particular treatments, figures within a column having similar letter(s) do not differ significantly at $\mathrm{P} \leq 0.05$ by DMRT; $\mathrm{T}_{0}=$ BARI Dherosh-1 (Control), $\mathrm{T}_{1}=\mathrm{JO}-1, \mathrm{~T}_{2}=\mathrm{JO}-2, \mathrm{~T}_{3}=\mathrm{JO}-3, \mathrm{~T}_{4}=\mathrm{JO}-4, \mathrm{~T}_{5}=$ Indian, $\mathrm{T}_{6}=$ Orka Onamika, $\mathrm{T}_{7}=$ Bankim, $\mathrm{T}_{8}=$ Durga, $\mathrm{T}_{9}=$ China and $\mathrm{T}_{10}=$ Thai.

Different cultivars had significant difference in fruit diameter (Fig.2). The highest fruit diameter $(1.47 \mathrm{~cm})$ was found in the cultivar $\mathrm{JO}-1$ followed by $\mathrm{JO}-3$ and the lowest fruit diameter $(1.21 \mathrm{~cm})$ found in Orka Onamika. Generally fruit length and diameter are closely related and both of them affected by growing condition and intercultural management. With the advancement of growth stages as well as with the increasing of plant ages both fruit length and diameter reduced gradually. Sajjan et al. (2003) stated that early formed fruits (as first) give highest length and girth those were reduced gradually with $5^{\text {th }}$ fruits onwards and the lowest was seen in 8th fruit. Islam (1997) showed that fruit diameter differed significantly in different genotypes. Saifullah et al. (2009) also reported the variation in fruit diameter from 1.26 to $2.12 \mathrm{~cm}$. Saha (2013) spectacled fruit diameter between 1.20 and $1.67 \mathrm{~cm}$ among 8 different cultivars. Single fruit weight differed significantly among the cultivars (Fig. 2). It was ranged from 10.62 to $14.48 \mathrm{~g}$. The highest fruit weight (14.48 g) was recorded in the cultivar $\mathrm{JO}-3$ which was statistically similar with JO-1. The cheapest fruit weight (10.62 g) was found in China. This result is in agreement with the findings of Saha (2013) and Saifullah et al. (2009). They indicated the variation in individual fruit weight among the large number of okra genotypes. Islam et al. (2000) also explain individual fruit weight differed significantly among different genotypes. The cultivars significantly varied in number of seeds fruit ${ }^{-1}$ (Fig. 2). The range varied from 42 to 69 . The maximum number of seeds fruit ${ }^{-1}$ (69) was recorded in the cultivar JO-1 and the depressed number of seeds fruit $^{-1}$ (42) obtained from the cultivar China. Saifullah et al. (2009) described number of seeds fruit ${ }^{-1}$ varied from 25 to 92 among 121 genotypes of Okra. Identical variation was also observed by Islam (1997) and Halim (2008). Seed size varied significantly among the cultivars which influenced the 100 seed weight (Fig. 2). It was varied from $4.59 \mathrm{~g}$ to $6.46 \mathrm{~g}$. The heaviest seeds $(6.46 \mathrm{~g})$ were found in the variety BARI Dherosh1. The lightest seeds $(4.59 \mathrm{~g})$ were found from the variety China. Other cultivars showed intermediate seed weight within the range. Variation in the 100 seed weight was genetically controlled characters and may be affected by availability of food materials in the initially formed fruits. Saha (2013) obtained 4.77 to $6.62 \mathrm{~g}$ in 100 seed of Okra. Similar variation observed by Saifullah et al. (2009) where weight of 100 seeds varies from 5.50 to $8.25 \mathrm{~g}$. It was appeared that the highest $\left(17.15 \mathrm{t} \mathrm{ha}^{-1}\right)$ fruit obtained in cultivar JO-3 and lowest (11.12 $\mathrm{t} \mathrm{ha}^{-1}$ ) fruit yield was recorded in cultivar JO-4 (Fig. 2). The yield is the result of complex interaction of the parameter like no. of fruit, fruit setting (\%), individual fruit weight. Yield (t) $\mathrm{ha}^{-1}$ between 9.28 and 12.56 found in research work among 8 cultivars of Okra by Saha (2013). Saifullah et al. (2009) reported fruit yield ha-1 of land from 2.76 to 19.24 tones among 121 genotypes. Islam et al. (2000) reported analogous variation in fruit yield ha $^{-1}$ ranged from 4.72 to 10.08 tones. 


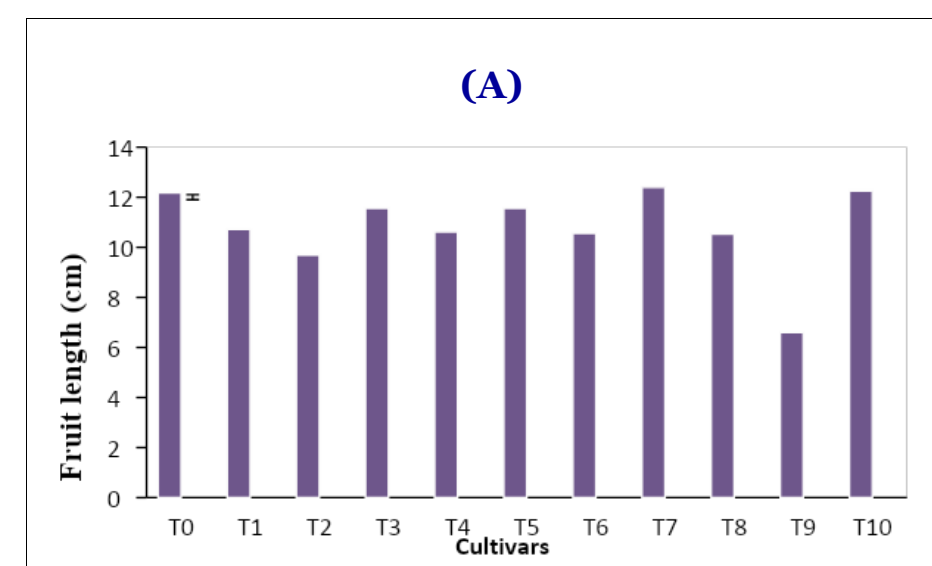

(C)

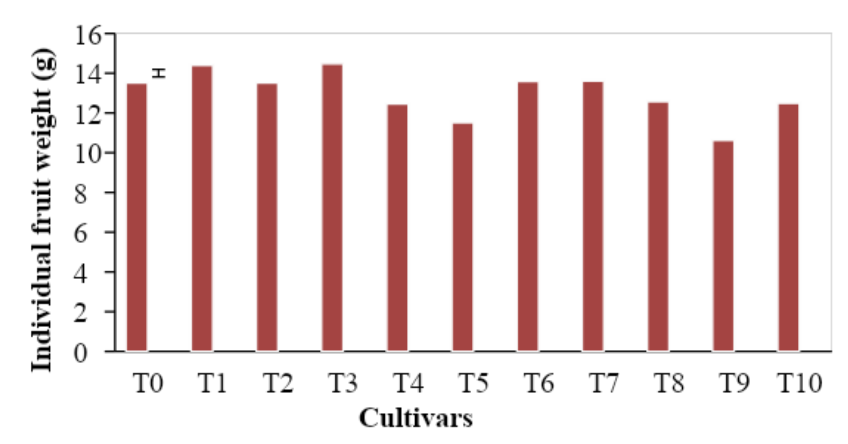

(E)

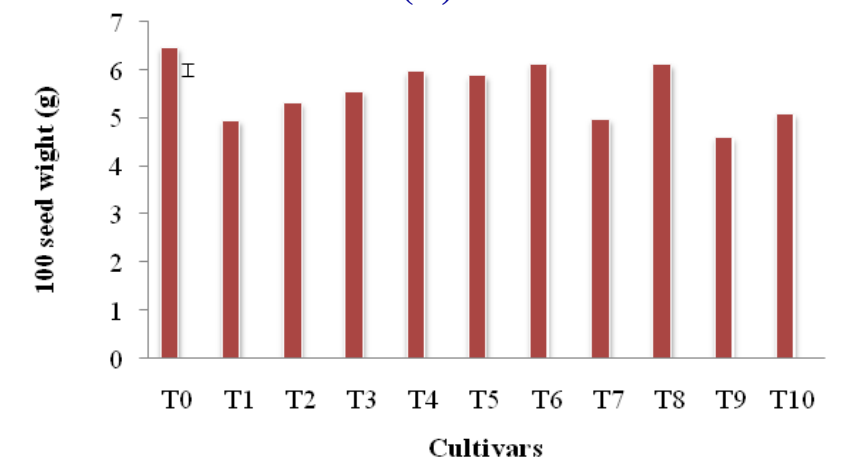

(B)

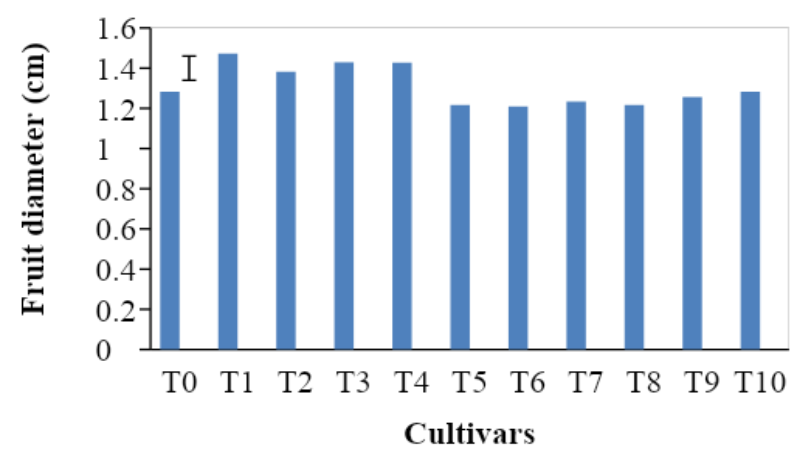

(D)

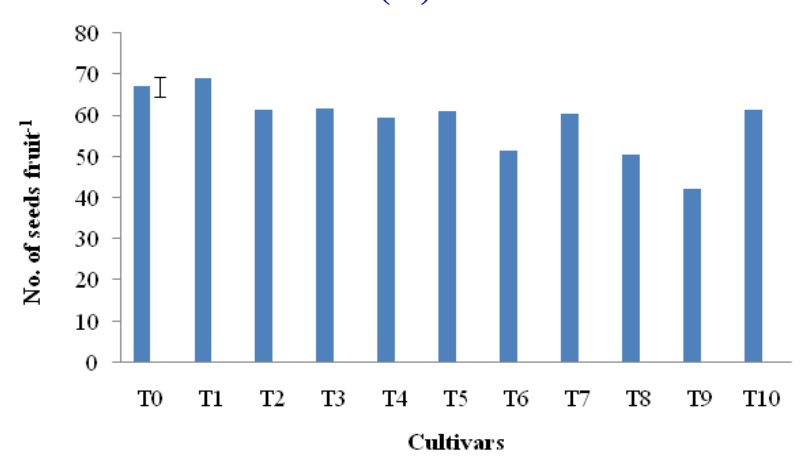

(F)

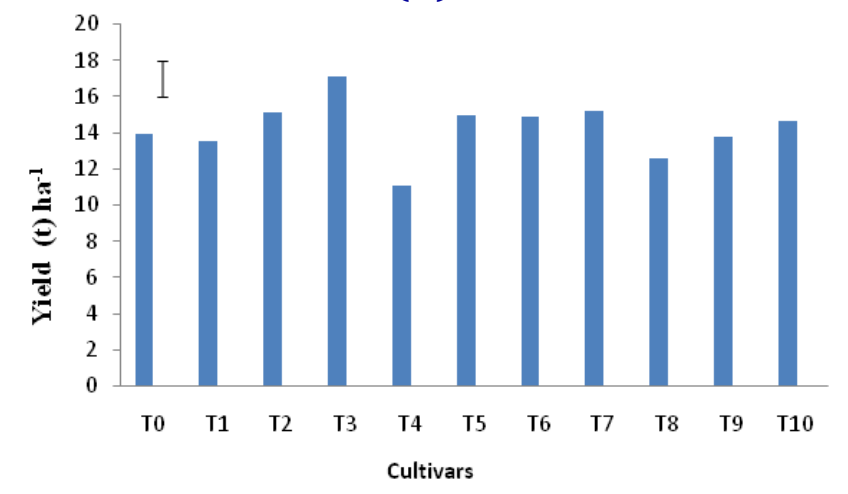

Fig. 2. Variation in fruit length $(\mathrm{cm})$, fruit diameter $(\mathrm{cm})$, individual fruit weight $(\mathrm{g})$, no. of seeds fruit ${ }^{-1}$, $100 \mathrm{seed}^{\mathrm{s}}$ weight $(\mathrm{g})$ and yield $(\mathrm{t}) \mathrm{ha}^{-1}$ of different Okra cultivars. Vertical bar represents standard error. $\mathrm{T}_{\mathrm{o}}=$ BARI Dherosh-1 (Control), $\mathrm{T}_{1}=\mathrm{JO}-1, \mathrm{~T}_{2}=\mathrm{JO}-2, \mathrm{~T}_{3}=\mathrm{JO}-3, \mathrm{~T}_{4}=\mathrm{JO}-4, \mathrm{~T}_{5}=$ Indian, $\mathrm{T}_{6}=$ Orka Onamika, $\mathrm{T}_{7}=$ Bankim, $\mathrm{T}_{8}=\mathrm{Durga}, \mathrm{T}_{9}=$ China and $\mathrm{T}_{10}=$ Thai.

\section{Conclusion}

Present research revealed the yield contributing characters of Okra cultivars. There were significant differences among the cultivars. None of the cultivars explained all rounding performance in all parameters studied. Though different cultivars showed varied performances in different parameters, the investigations suggest that the cultivar Bankim and JO-3 were very promising for better yield in acidic soil conditions of Sylhet. They are well fit in a cropping pattern that would 
increase the cropping intensity as well as net crop in the region. The cultivar $\mathrm{JO}-3$ showed better performance for its fruit size, shape softness, and yield.

\section{Conflict of interest statement}

Authors declare that they have no conflict of interest.

\section{References}

Abusaleha, A., Shanmugavelu, K. G., 1988. Studies on the effect of organic and inorganic source of nitrogen on growth yield and quality of okra [Abelmoschus esculentus (L.) Monech]. Indian J. Hort. 45(3-5), 312-318.

Anonymous, 2012. Status of horticultural crop production in Sylhet region. Paper presentation in the Workshop on Prospects of Horticultural crop production in Sylhet region, held on 17 November 2012, Sylhet Agricultural University, Sylhet.

BBS (Bangladesh Bureau of Statistics), 2013. Year Book of Agricultural Statistics of Bangladesh. Government of the People's Republic of Bangladesh. 39p.

Gopalakrishnan, T. R., 2007. Vegetable crops. Hort. Sci. Series 4. pp.32-33.

Halim, M. A. 2008. Seed yield and seed quality of some Okra [Abelmoschus esculentus (L.) Moench] cultivars. M.S. Thesis. Dept. of Horticulture, BSMRAU. pp.28-39.

Hossain, Z., 1997. Inheritance of yellow vein mosaic disease resistance and yield components in Okra [Abelmoschus esculentus (L.) Moench]. M.S. Thesis. Dept. of Genetics and Plant Breeding, Institute of Post Graduate Studies in Agriculture, Salna, Gazipur. pp.1-40.
Islam, M.S., 1997. Off season performance of Okra for vegetable and seed production. M.S. Thesis. Dept. of Horticulture, BSMRAU, Salna, Gazipur. pp.26-52.

Islam, M.S., Rahman, M. M., Ali, M., 2000. Off season production of Okra as affected by sowing time. Ann. Bangl. Agric. 10(1), 105-112.

Ndunguru, J., Rajabu, A., 2004. Effect of Okra mosaic virus disease on the above-ground morphological yield components of Okra in Tanzania. Sci. Hortic. 99, 225-235.

Prakash, M., Kannan, K., Kumar, J. S., Ganesan, J., 2001. Studies on the genetics of certain quantitative characters with particular reference to seed production in Okra. Ann. Agric. Res. 22(1), 80-82.

Russell, D. F., 1986. MSTAT-C package programme. Crop and Soil Science Department, Michigan State University, USA.

Saha, S. R., 2013. Physico-morphological features and yield attributes of exotic and local Okra cultivars in acid soil. M. S. Thesis. Dept. of Crop Botany and Tea Production Technology, SAU, Sylhet-3100. pp.16-34.

Saifullah, M., Rabbani, M. G., 2009. Evaluation and characterization of Okra [Abelmoschus esculentus (L.) Moench] genotypes. Saarc. J. Agric. 7(1), 92-99.

Sajjan, A. S., Pawar, K. N., Yakrnahal, B. S. V., 2003. Position effect of fruit on seed content and its quality in Okra. Orissa J. Hort. 31(2), 22-23.

Sanchez, P. A., Stoner, E. R., Pushparajah, E. D., 1987. Management of acid tropical soils for sustainable agriculture. Proceeding of IBSRAM Inaugural workshop. Bangkok, Thailand. 107p.

Varmudy, V., 2011. Needs to Boost Okra Exports: Market Survey, 21-22. Accessed on $21^{\text {st }}$ July, 2014 .

\section{How to cite this article:}

Shawon, Md. R. A., Saiful Islam, A. F. M., Moonmoon, S., 2020. Yield and yield attributes of exotic and local okra (Abelmoschus esculentus) cultivars in acid soil. Int. J. Curr. Res. Biosci. Plant Biol. 7(5), 7-12. doi: https://doi.org/10.20546/ijcrbp.2020.705.002 